As the contributors to Hanna's volume make us realise afresh, these are deeply engaging questions for any member of a modern society. The interest of reading this book derives in large part from the fact that we all have commitments, one way or another, on the issues with which it is concerned. However, it is not the purpose of Hanna's book to answer these questions, and much of the time they are, indeed, not even addressed in any head-on fashion. This book is a chronicle of the development of these debates by means of case studies, not a contribution to them. By and large this historical, non-philosophical approach is fairly strictly adhered to by the contributors who write the main articles, although annexed to these there are commentaries which open up the ethical issues a little more explicitly.

We are, as I say, predisposed to care about stories which raise these questions; and moreover it is of obvious value to writers on the more purely theoretical side of medical ethics to keep themselves in close contact with developments in actual science and actual debate. For one thing, scientific developments happen so quickly (and academic articles reach print so slowly) that there is a real danger that current medical technology will simply leave would-be ethical commentators behind. For another thing, there is a regrettable disparity between academic debate and the rest of the debate about these issues. As this book's sections on (in particular) the abortion issue in the USA show all too clearly: the debate which is actually going on in the political and public arenas is dominated, on both sides, not by the fine distinctions of such writers as Rosalind Hursthouse and Judith Jarvis Thomson, but by knee-jerk reactions and public hysteria. Theorists have to keep in mind the size of the gap which they ought to try to close.

The prose-style of the writers ought to have attracted more criticism from the editor, and more direction towards standardisation, than it seems to have done. At best, we get some very readable technical English (as in the last contribution). At worst (as too often elsewhere), we get a painful and ungainly cross-over dialect compounded from Newsweek journalese and both soft and hard scientific jargon, and peppered with abbreviations, acronyms and special usages which are explained at most once. (For example: 'While ddI was always closely linked with the concept of parallel track, once it became clear that it would take time to develop the concept into a working system, ddI and parallel track decoupled, at least in terms of a bureaucratic response'.)

However, this is just an immediately visible flaw in what (as persistence shows) is a very worthwhile piece of work. It is worthwhile, not only because it provides historical, political and sociological analysis of some recent controversial developments in medicine, but also because it provides students of medical ethics with the raw factual data which their work must take into account if it is not rapidly to become irrelevant and out of touch.

T D J CHAPPELL funior Research Fellow in Philosophy, Wolfson College, Oxford.

\section{Treat me right: essays in medical law and ethics}

Ian Kennedy, 428 pages + xviii, Oxford, 1991, Clarendon Press, $£ 14.95 \mathrm{pb}$

Ian Kennedy is Professor of Medical Law and Ethics at King's College, London, and Director of the Centre under that name, which he has made eminent. He knows as well as anyone what harm a money-grabbing litigiousness can do to the practice of medicine where it is rampant. He knows also what fantasies and ideological contentions 'ethicists' and propagandists can conjure up with scant regard to law or professional obligation. In the twenty chapters of this superb book he demonstrates with forceful lucidity how the common law, existing first for the protection of our liberties, is also the protector of an ethics of medicine grounded in the concept of duty: the duty of care required of one professing - that is, offering to patients in their vulnerability - the skills of medicine.

The papers date from 1973. All except the two last were published in the first hardback edition in 1988 . Only the last two, therefore, will be noticed in detail here. But many of the others are of lasting value because of their careful analysis of the judgements in the cases - like re $B, 1981$, Gillick, 1985, and Sidaway, 1985 brought to the courts by the ethical dilemmas of this decade, and formative of the law now governing practice. Kennedy has had his days of fame as a critic - and he is one still; here is established also his durable reputation as an expositor.

In the chapter on A Woman and her Unborn Child, Kennedy asks what compulsion or limitation upon a woman is expedient and tolerable on occasions of serious conflict between her interests and those of the fetus in her womb? The English courts would not entertain actions, like those cited from the USA, to compel a woman to undergo caesarean section; neither would they extend custody or wardship over an unborn child. The protection of fetal interests, whose claim grows stronger pari passu with growth towards maturity, rests on maternal duty: the fetus has no legal right in itself until born alive. An exercise in moral calculus is then offered to yield criteria by which conflicts of interest may be adjusted or resolved. Kennedy, resisting pressure from the USA, would not advocate a statutory enactment to invest the fetus with rights or to give the law direct power over it. In general he would rely on education and social persuasion. The most he can contemplate is a statute which would empower a judge, in an outstanding case of flagrant threat to fetal interest, to weigh the moral calculus judicially and, if so determined, to authorise surgical intervention, or wardship of the unborn, or a care order at birth, for each case individually. He would prefer not to make this change, but rather to leave the fate of the unborn child to its mother, lest more legal regulation of her conduct be bought at too high a price.

The essay Patients, Doctors and Human Rights began as a chapter for a book entitled Human Rights for the 1990s. This perhaps explains a remarkable change: Ian Kennedy the common lawyer becomes a 'human rights lawyer'; and words written wisely and cogently, in earlier essays are now translated polemically into the language of rights, or repudiated if they will not fit. On page 78 he quotes with approval a conclusion of Woolf, J which 'allows for a legal analysis of the doctor's conduct based on the central legal and ethical concept of duty'. On page 318 he writes: 'If there is a unifying premiss which informs the law it is to be found, I submit, in the concept of duty'. Yet in this new chapter, at page 386 , he ends a loose 
scrimmage against the medical profession with: 'However, . . . there is still the tendency to state and analyse the law wholly in terms of duties, the duties of doctors and perhaps of patients, so as to avoid what is perceived (wrongly) as the more oppressive language of rights'. . . . Hence, 'I will adopt here a frank assertion of rights inherent in the doctor-patient relationship'. In this he relies on dicta of Lord Scarman in Sidaway, where he grounded the doctor's duty to inform in the patient's legal right to accept or reject the treatment proposed (page 202). But Scarman also asserted (page 194) that the 'proper place' of a duty to warn a patient of risk is 'as an aspect of the duty of care owed by the doctor to his patient'. And the Lords, in their judgements, preferred the language of duties also, to Kennedy's evident regret.

However, Kennedy allows that the rights which he champions are prima facie or presumptive rights, not absolute; and that there are circumstances in which a patient's 'rights' may require that he be not informed. It is therefore by no means clear what is gained by a change of language: the doctor is still left with the duty of weighing and serving the patient's interests within the overall protection of the patient's liberties safeguarded by the law.

Kennedy is clearly provoked by two decided cases of non-consensual sterilisation in which those liberties were, in his view, not safeguarded: re $B$ (1987) and re $F$ (1989), both of mentally handicapped women, the first a minor. He profoundly regretted the judgement in re $B$ in terms of best interests, and those evidenced by untested reliance upon expert witnesses. In the examination of re $F$ Kennedy the common lawyer and Kennedy the human rights lawyer seem to be at odds. To the statement of the law contained in the Lord's judgement - that no one has authority to consent to the treatment of another adult, albeit incompetent, and therefore no court can; but that, since this would leave the incompetent legally untreatable, treatment could be declared lawful if justified by necessity or as being in the public interest, which would include the patient's interest - and to the practice directions given in consequence, Kennedy gives reluctant approval: they represent 'a significant public commitment to respect for human rights', 'although not overtly speak- ing the language of human rights'. But for the judgement on the case itself, 'approached from the perspective of human rights on the basis of first principles', he cannot say that the Lords' view 'that non-consensual sterilisation is lawful subject to certain conditions being satisfied' was valid and correct; he regretted it. Conversely, he says, it is an unjustifiable violation of human rights if carried out for non-therapeutic reasons and, as a consequence, should be declared unlawful' (page 407, italics his). On this he would stand against all collusion with utility and pragmatism despite his allowance that what is prima facie unlawful might in certain circumstances be declared lawful (page 410).

In all this Kennedy re-appears as the consistent protector of the patient against his old enemy, 'medical paternalism', and against courts which collusively decide cases on patients' interests as defined by medical witnesses: 'After all, is it not the role of one professional elite to protect another?' And this protection, he maintains, requires the assertion of 'rights'. But does it? For the human rights lawyer, he says, the 'starting point for analysis will, as ever, be a concern to protect the vulnerable from real or potential oppression or exploitation. In our case, as in most, this will translate as the need to justify any medical intervention by reference to carefully articulated criteria' (pages 396-397). What, then, is new? Is it not already the function of the courts of common law to protect the liberties of the subject? But read on: 'Oppression or exploitation may take other forms. It must be recognised that it is equally oppressive to deny an incompetent person treatment which would otherwise be judged appropriate. Whatever criteria are developed to protect the incompetent must, therefore, bear in mind that the cause of human rights is not served by so concentrating on the protection of the incompetent that it is forgotten that a significant means of protecting him may be to treat him'. Have we not returned to a familiar moral calculus, an exercise in moral reasoning, basic to the ethics and law of medical practice, into which the rhetoric of rights is an unnecessary intrusion?

G R DUNSTAN

Honorary Research Fellow, Department of Theology, University of Exeter.
Introduction to risk calculation in genetic counselling

Ian D Young, 160 pages, Oxford, 1991, Oxford University Press, $£ 22.50 \mathrm{hb}, £ 12.50 \mathrm{pb}$

Only a few years ago the parents of boys with sex-linked genetic conditions might have been given a $50 / 50$ chance that any further boys they had would be affected. The rapid advances in molecular biology have introduced crucial new information from DNA marker studies which enable more precise estimations of carrier and recurrence risks to be made. Calculating genetic risks has always been complicated but the advent of DNA probes and linked markers, coupled with the need to take account of cross-over rates and the application of screening for specific mutation points, has added further complexities. In a field that is changing so rapidly an up-to-date book that deals with the mathematical aspects of genetic counselling is badly needed.

This volume from Ian Young will be a welcome addition to the tools available to other clinical geneticists. Dr Young has succeeded in his aim of producing a user-friendly guide to the methods for risk calculation in genetic counselling. Separate chapters deal with autosomal dominant, autosomal recessive and sex-linked inheritance patterns and the incorporation of Bayesian calculations. The book also includes discussion of the factors that influence the transmission risks of chromosomal re-arrangements and their likely viability. The book has many worked examples with family pedigrees that are clearly drawn out and annotated, to lead the nonmathematician through to a safe risk estimation.

Although each example is explained line by line, the background to each concept is perhaps too brief confidently to allow everyone to master all the techniques from scratch. The book should not be regarded as a teach-yourself-guide for everyone, but rather as one which can consolidate previous teaching. It will serve well as a textbook for those training in medical genetics and will be an essential reference for clinical problems. The author's approach to problem-solving becomes easy to follow and is reassuringly consistent 